\title{
Propranolol inhalation challenge in relation to histamine response in children with asthma
}

\author{
J GERRITSEN, G H KOËTER, L T VANDERWEELE, K KNOL \\ From the Paediatric and Internal Departments of Pulmonology, and the Computing Centre, University Hospital, \\ Groningen, and University of Groningen, The Netherlands
}

\begin{abstract}
The relation between airway responsiveness to propranolol and histamine was studied in 32 asthmatic children. Propranolol and histamine were given by nebuliser to a maximum dose of 16 $\mathrm{mg} / \mathrm{ml}$ and $32 \mathrm{mg} / \mathrm{ml}$ respectively and the response was measured as the provocative concentration of agonist causing a $20 \%$ fall in $\mathrm{FEV}_{1}\left(\mathrm{PC}_{20}\right)$. A PC $\mathrm{PC}_{20}$ histamine value of less than $32 \mathrm{mg} / \mathrm{ml}$ was obtained in 24 of the 32 children, of whom 15 had a measurable $P_{20}$ propranolol $(<16 \mathrm{mg} / \mathrm{ml})$. In these 24 children the geometric mean $\mathrm{PC}_{20}$ histamine was $4.5 \mathrm{mg} / \mathrm{ml}$ and $14.4 \mathrm{mg} / \mathrm{ml}$ respectively in those with and without a measurable $\mathrm{PC}_{20}$ propranolol $(\mathrm{p}=0.023)$. There was a linear relationship between histamine and propranolol $\mathrm{PC}_{20}$ values $(\mathrm{r}=0.60)$, and between $\mathrm{PC}_{20}$ histamine and $\mathrm{FEV}_{1} \%$ predicted $(r=0.43)$, but not between $P_{20}$ propranolol and $F E V_{1} \%$ predicted $(r=0.38)$. In an open time course study in 12 children with asthma recovery of $\mathrm{FEV}_{1}$ after inhaled propranolol was incomplete in seven of the children after 90 minutes. When inhaled propranolol was followed by inhaled ipratropium bromide in a further 11 children $\mathrm{FEV}_{1}$ had returned to baseline in all children after 60 minutes. Thus propranolol inhalation can be used in children with asthma to assess the contribution of the $\beta$ adrenergic system to the regulation of bronchial smooth muscle tone. The test has several disadvantages in comparison with histamine provocation-long duration, the prolonged action of propranolol, and the fact that only the children with substantial hyperreactivity to histamine react to propranolol.
\end{abstract}

\section{Introduction}

Soon after the introduction of the non-selective $\beta$ receptor blocking agent propranolol, it was reported that administration could lead to bronchoconstriction in patients with asthma, ${ }^{12}$ whether the drug was administered orally, intravenously, or by inhalation..$^{1-4}$ The development of bronchoconstriction after propranolol has been considered by some workers to be a feature of bronchial hyperreactivity. ${ }^{56}$ Bronchial hyperreactivity is often assessed as the airway response to histamine or methacholine, agonists acting on histamine and muscarinic receptors on bronchial smooth muscle. ${ }^{7-10}$ The adrenergic system can be considered as a counter-regulating mechanism," causing bronchodilatation and attenuating bronchial hyperreactivity.

In the present study the relation between propranolol and histamine responsiveness of the airways

Address for reprint requests: Dr Jorrit Gerritsen, Department of Paediatrics, Division of Paediatric Pulmonology, 59 Oostersingel 9713 EZ Groningen, The Netherlands.

Accepted 23 March 1988 was investigated in children with asthma, to assess the relation between the $\beta$ adrenergic action on the airways and the degree of bronchial hyperreactivity. Children with increased airway reactivity were expected to be more likely to develop bronchoconstriction with propranolol. If they did, a clear relation between the degree of responsiveness to histamine and to propranolol was to be expected. In addition, the time course of change in $\mathrm{FEV}_{1}$ after propranolol inhalation was determined. The influence of inhaled ipratropium bromide on this time course was documented in a parallel group of children.

\section{Methods}

\section{PATIENTS}

Fifty five asthmatic children (20 girls), aged 9-15 years, were studied after we had received informed consent from both the children and their parents. The study was approved by the institution's committee on clinical investigation. The diagnosis of asthma was based on a history of episodic shortness of breath or wheezing (or both), either permanently or episodically. All the children were judged atopic on the 
basis of a positive skin response to at least one allergen on skin testing. Baseline $\mathrm{FEV}_{\text {, values were not below }}$ $70 \%$ of predicted..$^{12}$ At the time of the study asthma was under control and none of the subjects was receiving oral corticosteroids or sustained release theophylline preparations. Maintenance treatment included sodium cromoglycate or low dose inhaled corticosteroids and a $\beta_{2}$ agonist on an "if needed" basis; this was withheld for at least 24 hours before each test.

In 32 children propranolol and histamine challenges were performed. In 23 children known to develop bronchoconstriction in response to propranolol the time course of the FEV, change was determined after inhalation of propranolol alone (12 children) or after inhalation of propranolol followed by ipratropium bromide.

\section{HISTAMINE CHALLENGE}

Aerosols of test solutions were generated by passing air through a gauged Wiesbadener Doppelinhaler at a flow rate of $8 \mathrm{l} / \mathrm{min}$ as described previously. ${ }^{13}$ This results in an aerosolised volume of $110-120 \mu \mathrm{l} / \mathrm{min}$ and a droplet size of less than $5 \mu \mathrm{m} .{ }^{14}$ Aerosols were inhaled by tidal breathing for 30 seconds. The children wore a nose clip during inhalation and lung function manoeuvres. After having baseline spirometry the children inhaled a control solution of saline $9 \mathrm{~g} / \mathrm{l}$, followed at three minute intervals by doubling concentrations of histamine acid phosphate, starting at $0.25 \mathrm{mg} / \mathrm{ml}$ and going up to a maximum of $32 \mathrm{mg} / \mathrm{ml}$. A water seal spirometer (Spirograph, Lode spirometer D75, Groningen, The Netherlands) was used for measurements of the inspiratory slow vital capacity

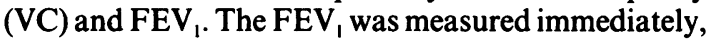
and again three minutes after each inhalation. Inhalations were discontinued when the $\mathrm{FEV}_{1}$ had fallen by $20 \%$ from baseline $F E V_{\text {, }}$ or after the $32 \mathrm{mg} /$ $\mathrm{ml}$ concentration of histamine had been administered.

\section{PROPRANOLOL CHALLENGE}

Propranolol inhalation tests were carried out at least 60 minutes after the histamine challenge test and when the $\mathrm{FEV}_{1}$ had returned to within $95 \%$ of baseline. Propranolol solutions were nebulised in the same way as histamine, and inhaled for two minutes in accordance with the propranolol provocation scheme in adults. ${ }^{51}$ The challenge was performed with the following concentrations of propranolol in saline $9 \mathrm{~g} / \mathrm{l}$ : $1 \cdot 0,2 \cdot 0,4 \cdot 0,8 \cdot 0$, and $16 \cdot 0 \mathrm{mg} / \mathrm{ml}$. The solutions had a $\mathrm{pH}$ of $6.60,6.42,6.30,6.20$, and 5.98 respectively. Inhalations were stopped when the FEV, had fallen by $20 \%$ from the baseline value, or after the maximum concentration had been administered.

TIME COURSE OF CHANGE IN FEV 1 AFTER

PROPRANOLOL INHALATION

The time course of change in $\mathrm{FEV}_{1}$ after challenge with propranolol was measured in an open study in paralle groups of 12 and 11 children, selected on the basis of having a bronchoconstrictor response to inhaleag propranolol. In the first group change in $\mathrm{FEV}_{1}$ after. inhaled propranolol was followed for up to 98 minutes. In the second group ipratropium bromide $0.25 \mathrm{mg} / \mathrm{ml}$ was inhaled for two minutes (Wiesbadenep doppelinhaler) 15 minutes after the propranol challenge, and change in $\mathrm{FEV}_{\text {, }}$ was followed for further 45 minutes.

ANALYSIS OF RESULTS

Response to histamine and propranolol was expressed as the provocation concentration of agonist require to cause a $20 \%$ fall in $\mathrm{FEV}_{1}\left(\mathrm{PC}_{20}\right)$. This was obtainect by fitting a "smoothed" curve to the last three points on the dose-response curve with the help of a Cyber computer, the concentration being measured at $80 \%$ of the pretest $\mathrm{FEV}_{1} .^{15}$ Logarithmic transformation were applied to all $\mathbf{P C}_{20}$ values before analysis. $\mathbf{P C}_{20}^{D}$ values $(\mathrm{mg} / \mathrm{ml})$ are presented as geometric means, an $\$$ $\mathrm{FEV}_{1}$ values as means with standard errors. The relationship between $\mathrm{PC}_{20}$ propranolol and $\mathrm{PC}$ histamine values and baseline $F E V_{1}$ (as percentages predicted values) was assessed by means of Pearson correlation coefficient. Student's $t$ test for unpaired observations was used to compare the $\mathrm{FEV}_{1}$ 哆 predicted values of children with a $\mathrm{PC}_{20}$ propranolol of $16 \mathrm{mg} / \mathrm{ml}$ or less and of those with a value of more thay $16 \mathrm{mg} / \mathrm{ml}$. Statistical analysis of the data was perfor med with the SPSS-X program (Statistical Package fow the Social Sciences, version X) on the University CDE Cyber 170/760 computer.

\section{Results}

Details of the children are given in tables 1 and 2. Aftê inhalation of the maximum concentration of propranolol $(16 \mathrm{mg} / \mathrm{ml})$ a few children complained of local irritation of the mouth and an unpleasant taste The mean $\mathrm{FEV}_{1}$ was $92.8(1 \cdot 1) \%$ predicted for all the children, ranging from $73 \%$ to $108 \%$. A $\mathrm{PC}_{\infty}$ histamine was obtained in 24 of the 32 childreps challenged with both histamine and propranolol. $Q_{S}$ these 24 children, 15 had a measurable $P_{20}$ prơ pranolol and nine did not. All of the 14 children with $\mathrm{PC}_{20}$ histamine of value of more than $16 \mathrm{mg} / \mathrm{ml} \mathrm{had}$ $\mathrm{PC}_{20}$ propranolol of more than $16 \mathrm{mg} / \mathrm{ml}$.

PC $_{20}$ PROPRANOLOL VERSUS PC 20 HISTAMINE

There was a linear relationship between $P_{20}$ hi tamine and $\mathrm{PC}_{20}$ propranolol in the 15 children with measurable $\mathrm{PC}_{20}$ value with both agonists $\left(r=0.60_{3}\right.$ $P=0.018$; fig 1). The geometric mean $\mathrm{PC}_{20}$ histamine in the 15 children with a $\mathrm{PC}_{20}$ propranolol of $16 \mathrm{mg} / \mathrm{m}$. or less was $4.5 \mathrm{mg} / \mathrm{ml}$, compared with a mean P\& 
Table 1 Characteristics of 32 children receiving histamine and propranolol challenges

\begin{tabular}{|c|c|c|c|c|c|}
\hline $\begin{array}{l}\text { Age } \\
(y)\end{array}$ & Sex & Medication* & $\begin{array}{l}F E V_{1} \\
\text { (\% pred) }\end{array}$ & $\begin{array}{l}P C_{20} \\
\text { histamine } \\
(\mathrm{mg} / \mathrm{ml})\end{array}$ & $\begin{array}{l}P C_{20} \\
\text { propranolol } \\
\text { (mg/ml) }\end{array}$ \\
\hline $\begin{array}{r}13 \\
11 \\
11 \\
10 \\
9 \\
12 \\
11 \\
10 \\
9 \\
10 \\
10 \\
14 \\
13 \\
11 \\
14 \\
12 \\
10 \\
15 \\
11 \\
12 \\
12 \\
13 \\
13 \\
14 \\
10 \\
9 \\
12 \\
14 \\
9 \\
13 \\
10 \\
11\end{array}$ & $\begin{array}{l}\mathbf{F} \\
\mathbf{M} \\
\mathbf{M} \\
\mathbf{M} \\
\mathbf{M} \\
\mathbf{F} \\
\mathbf{F} \\
\mathbf{M} \\
\mathbf{M} \\
\mathbf{M} \\
\mathbf{M} \\
\mathbf{F} \\
\mathbf{F} \\
\mathbf{M} \\
\mathbf{F} \\
\mathbf{M} \\
\mathbf{F} \\
\mathbf{M} \\
\mathbf{M} \\
\mathbf{M} \\
\mathbf{M} \\
\mathbf{M} \\
\mathbf{F} \\
\mathbf{M} \\
\mathbf{M} \\
\mathbf{F} \\
\mathbf{F} \\
\mathbf{M} \\
\mathbf{M} \\
\mathbf{M} \\
\mathbf{F}\end{array}$ & $\begin{array}{l}\mathrm{C}, \beta \\
\mathrm{C}, \beta \\
\mathrm{S} \\
\mathrm{S} \\
\mathrm{C}, \beta \\
\mathrm{S}, \beta \\
\mathrm{C} \\
\mathrm{S} \\
\text { No } \\
\mathrm{S} \\
\mathrm{C} \\
\mathrm{C}, \beta \\
\mathrm{S} \\
\mathrm{C} \\
\mathrm{S}, \beta \\
\mathrm{C} \\
\mathrm{S} \\
\mathrm{S}, \beta \\
\text { No } \\
\mathrm{C}, \beta \\
\mathrm{S} \\
\mathrm{S} \\
\mathrm{C}, \beta \\
\mathrm{S} \\
\mathrm{S} \\
\text { No } \\
\mathrm{C} \\
\mathrm{S} \\
\mathrm{S} \\
\mathrm{S} \\
\mathrm{S} \\
\mathrm{C}\end{array}$ & $\begin{array}{r}83 \\
81 \\
88 \\
90 \\
82 \\
90 \\
83 \\
94 \\
105 \\
103 \\
88 \\
73 \\
99 \\
100 \\
83 \\
97 \\
95 \\
92 \\
94 \\
90 \\
94 \\
99 \\
87 \\
100 \\
99 \\
104 \\
96 \\
104 \\
101 \\
105 \\
100 \\
90\end{array}$ & $\begin{array}{r}1.1 \\
1.8 \\
7.6 \\
3.5 \\
1.8 \\
3.9 \\
3.2 \\
2.2 \\
14.2 \\
14.6 \\
5.8 \\
14.4 \\
10.6 \\
2.8 \\
4.2 \\
4.0 \\
24.0 \\
23.8 \\
18.0 \\
4.0 \\
10.0 \\
26.6 \\
19.3 \\
27.2 \\
>32.0 \\
>32.0 \\
>32.0 \\
>32.0 \\
>32.0 \\
>32.0 \\
>32.0 \\
>32.0\end{array}$ & $\begin{array}{r}1.2 \\
2.5 \\
4.5 \\
6.6 \\
6.9 \\
8.0 \\
9.5 \\
10.6 \\
11.0 \\
11.4 \\
11.7 \\
12.3 \\
13.1 \\
13.5 \\
13.6 \\
>16.0 \\
>>16.0 \\
>16.0 \\
>16.0 \\
>16.0 \\
>16.0 \\
>16.0 \\
>116.0 \\
>16.0 \\
>>16.0 \\
>>16.0 \\
>>16.0 \\
>>16.0 \\
>>16.0 \\
>>16.0 \\
>16.0 \\
>>16.0\end{array}$ \\
\hline
\end{tabular}

*S-sodium cromoglycate; $\mathrm{C}$-inhaled corticosteroids; $\beta$ sympathomimetic.

histamine of $14.4 \mathrm{mg} / \mathrm{ml}(\mathrm{p}=0.023)$ in the nine children with a $\mathrm{PC}_{20}$ propranolol of over $16 \mathrm{mg} / \mathrm{ml}$ and a measurable $\mathrm{PC}_{20}$ histamine.

PC $_{20}$ PROPRANOLOL AND FEV $1 \%$ PREDICTED

The mean $\mathrm{FEV}_{1} \%$ predicted for the children with a measurable $\mathrm{PC}_{20}$ with both propranolol and histamine (89.5\% (SEM 2.4\%)) did not differ significantly from values in children with a $\mathrm{PC}_{20}$ propranolol of over 16 $\mathrm{mg} / \mathrm{ml}$ and a $\mathrm{PC}_{20}$ histamine of $32 \mathrm{mg} / \mathrm{ml}$ or less $(94.2 \%$ (SEM 1.4\%)), but both groups had significantly lower values than children without a measurable $\mathrm{PC}_{20}$ with either challenge (99.9\% (SEM 1.8\%)), p being $<0.01$ and $<0.05$ respectively. No relationship was found between $\log \mathrm{PC}_{20}$ propranolol and $\mathrm{FEV}_{1} \%$ predicted values $(r=0.38 ; p=0 \cdot 17)$. A linear relationship was, however, found between $\log \mathrm{PC}_{20}$ histamine and $\mathrm{FEV}_{1} \%$ predicted values in the 24 children with a $\mathrm{PC}_{20}$ histamine $(r=0.43 ; p<0.05)$.

TIME COURSE OF FEV , AFTER PROPRANOLOL CHALLENGE AND THE INFLUENCE OF IPRATROPIUM BROMIDE

In seven of the 12 children given propranolol alone
Table 2 Characteristics of 23 children in whom the time course of $F E V_{1}$ after propranolol challenge was studied

\begin{tabular}{|c|c|c|c|c|c|}
\hline $\begin{array}{l}\text { Age } \\
(y)\end{array}$ & Sex & Medication* & $\begin{array}{l}P C_{20} \\
\text { propranolol } \\
(\mathrm{mg} / \mathrm{ml})\end{array}$ & $\begin{array}{l}F E V_{1} \\
\text { baseline (1) }\end{array}$ & $\begin{array}{l}F E V_{1} \\
\text { (\% pred) }\end{array}$ \\
\hline \multicolumn{6}{|c|}{ Twelve children whose FEV, improved without ipratropium bromide } \\
\hline 12 & M & C & 9.0 & 2.0 & 87 \\
\hline 12 & $\mathbf{M}$ & $\mathrm{S}, \mathrm{C}$ & 3.0 & 1.9 & 84 \\
\hline 12 & M & $\mathrm{S}$ & $15 \cdot 0$ & $2 \cdot 3$ & 99 \\
\hline 13 & $\mathbf{F}$ & No & 16.0 & $2 \cdot 8$ & 105 \\
\hline 12 & $\mathbf{M}$ & $\mathrm{S}, \boldsymbol{\beta}$ & $13 \cdot 3$ & 1.9 & 81 \\
\hline 15 & $\mathbf{M}$ & S & 9.9 & 3.6 & 103 \\
\hline 9 & $\mathbf{F}$ & $C, \beta$ & $12 \cdot 0$ & $1 \cdot 5$ & 92 \\
\hline 11 & $\mathbf{M}$ & $C, \beta$ & 13.0 & 1.9 & 82 \\
\hline 13 & M & $S, \beta$ & $16 \cdot 0$ & 1.9 & 80 \\
\hline 13 & M & S & $15 \cdot 6$ & $2 \cdot 1$ & 88 \\
\hline 13 & $F$ & $\mathbf{S}$ & $15 \cdot 0$ & $2 \cdot 7$ & 92 \\
\hline & $\mathbf{F}$ & No & $8 \cdot 7$ & $2 \cdot 4$ & 108 \\
\hline \multicolumn{3}{|c|}{$\begin{array}{l}\text { Mean } \\
12\end{array}$} & $11 \cdot 3$ & $2 \cdot 2$ & 92 \\
\hline \multicolumn{6}{|c|}{ Eleven children whose $F E V$, improved with ipratropium bromide } \\
\hline 10 & $\mathbf{M}$ & $\mathrm{S}$ & $10 \cdot 4$ & 1.5 & 88 \\
\hline 12 & $\mathbf{F}$ & $\mathbf{S}$ & $1 \cdot 3$ & $2 \cdot 3$ & 92 \\
\hline 12 & $\mathbf{F}$ & $\mathrm{C}, \beta$ & $14 \cdot 7$ & $2 \cdot 4$ & 84 \\
\hline 11 & $\mathbf{M}$ & S & $12 \cdot 2$ & $2 \cdot 8$ & 93 \\
\hline 14 & $\mathbf{F}$ & No & $16 \cdot 0$ & $2 \cdot 5$ & 85 \\
\hline 11 & $\mathbf{M}$ & S & $13 \cdot 5$ & $2 \cdot 1$ & 100 \\
\hline 14 & $\mathbf{F}$ & S & $6 \cdot 3$ & $2 \cdot 6$ & 99 \\
\hline 15 & $\mathbf{M}$ & $\mathrm{C}, \boldsymbol{\beta}$ & $12 \cdot 2$ & $2 \cdot 6$ & 84 \\
\hline 10 & $\mathbf{M}$ & S & $13 \cdot 2$ & $2 \cdot 1$ & 94 \\
\hline 11 & M & No & 10.0 & $2 \cdot 2$ & 100 \\
\hline & M & S & $7 \cdot 8$ & $2 \cdot \overline{1}$ & 92 \\
\hline \multicolumn{3}{|c|}{$\begin{array}{l}\text { Mean } \\
12\end{array}$} & $9 \cdot 2$ & $2 \cdot 3$ & 92 \\
\hline
\end{tabular}

${ }^{*} \mathrm{C}$-inhaled corticosteroids; S-sodium cromoglycate; $\beta$ sympathomimetic.

†FEV, before the test.

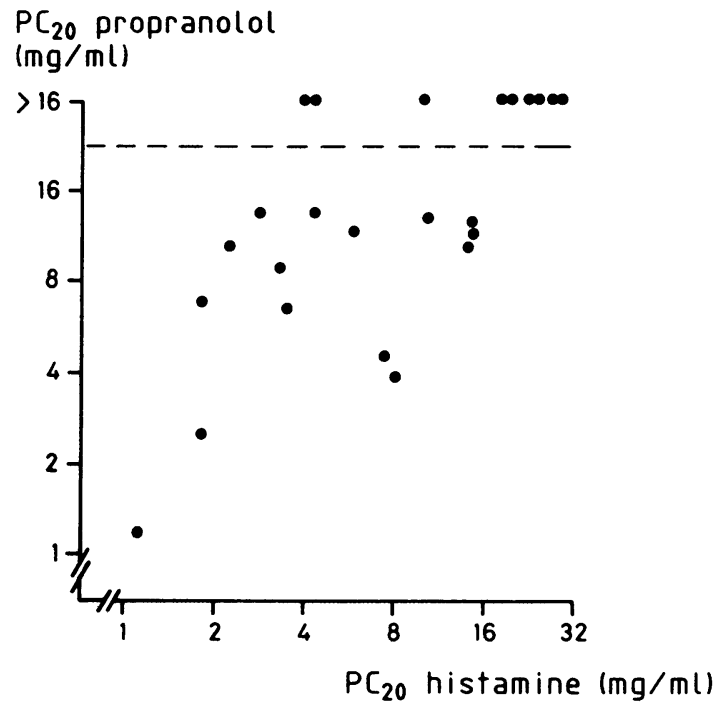

Fig 1 Provocative concentrations of histamine causing a $20 \%$ fall in $F E V_{1}\left(P C_{20}\right.$ histamine $)$ plotted against the $P C_{20}$ propranolol values $(r=0.60 ; p=0.018)$. The children who did not respond after inhalation of propranolol were assigned the value $>16 \mathrm{mg} / \mathrm{ml}$. 


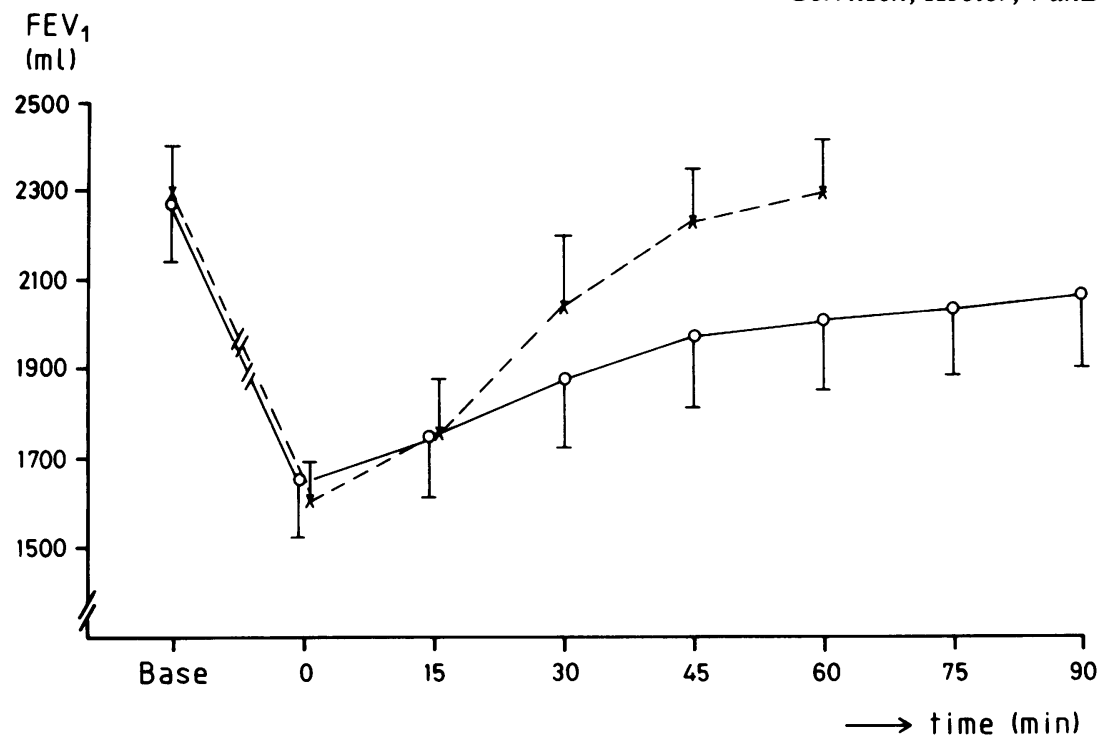

Fig 2 Mean FEV, before the test (base) and at threshold (0) after challenge with propranolol, and changes with time after threshold, during spontaneous recovery ( $O$ and after treatment with ipratropium bromide 15 minutes after threshold $(\times-\times)$.

$\mathrm{FEV}_{\text {, }}$ had not returned to within $5 \%$ of baseline values 90 minutes after challenge (fig 2). Recovery was faster in the children treated with ipratropium bromide after

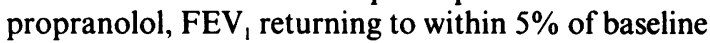
values by 60 minutes after propranolol in all 11 children (fig 2).

\section{Discussion}

In this study two thirds of the asthmatic children with a $\mathrm{PC}_{20}$ histamine of less than $32 \mathrm{mg} / \mathrm{ml}$ had a bronchoconstrictor response to inhaled propranolol. A similar finding was observed in adults. ${ }^{5} \mathbf{P C}_{20}$ histamine values were significantly lower in the children who developed bronchoconstriction in response to inhaled propranolol than in the propranolol non-responders. All the children with no response to inhaled histamine also had no response to inhaled propranolol. The $\mathbf{P C}_{20}$ histamine and the $\mathbf{P C}_{20}$ propranolol values were clearly correlated in the children with a response to both agents. Thus an increase in non-specific reactivity is associated with an increased sympathetic drive to the airways. No correlation was observed between $\mathbf{P C}_{20}$ propranolol and $\mathrm{FEV}_{1} \%$ predicted values.

The exact mechanism by which propranolol produces bronchoconstriction is not understood. It has been suggested that patients with asthma have increased cholinergic activity, and $\beta$ adrenergic activity may be considered as a counter balance to oppose bronchial obstruction. Blockade of $\beta$ adrenoreceptors by propranolol will leave theू cholinergic activity unopposed. ${ }^{16}$ This hypothesis is supported by the observation that in asthmatic patients prior administration of atropine can sub-3 stantially reduce or even block the bronchial response? to propranolol. ${ }^{16}{ }^{17}$ There is, however, no convincing. evidence suggesting how $\beta_{2}$ receptors are stimulated in asthmatic patients because under resting conditions circulating catecholamine concentrations are nof raised. $^{18}$

Other factors, such as mediator release from mase cells, may play a part in the bronchial constriction produced by propranolol. Propranolol can inducee histamine release from mast cells in vitro, ${ }^{19}$ and sodium cromoglycate can inhibit the propranolob response in vivo. ${ }^{20}$ No increase in circulating histamine was, however, observed after the intravenous adminis $N$ tration of propranolol to asthmatic subjects. ${ }^{21}$

Only children with a $\mathrm{PC}_{20}$ histamine of $16 \mathrm{mg} / \mathrm{ml}$ ô less had a measurable $\mathbf{P C}_{20}$ propranolol. A similaw relationship has been observed previously. Subjects with the lowest $\mathbf{P C}_{20}$ methacholine were mosto responsive to inhaled propranolol in one study, ${ }^{17}$ ando the fall in FEV , after ocular administration of the non $?$ selective $\beta$ blocker timolol correlated with the fall in $\mathrm{FEV}_{1}$ after an exercise challenge in another. ${ }^{22}$ Ou유 finding of a significant correlation between airway responsiveness to histamine and to propranolo $\mathbb{B}$ suggests that bronchial responsiveness to adrenoreceptor blockade is substantially related to airway reactivity. The fact that prior administration of 
atropine can block the response to propranolol suggests that it is predominantly determined by the degree of parasympathetic tone in the airways.

Histamine responsiveness was correlated with the degree of bronchial obstruction before challenge as in other studies. ${ }^{1323} \mathrm{~A}$ similar relationship between $\mathbf{P C}_{20}$ propranolol and FEV, \% predicted values could not be found, possibly because we included only those children with an FEV, value of $70 \%$ or more. In adults the correlation between $\mathrm{FEV}_{1}$ and airway reactivity is closer when $\mathrm{FEV}_{1}$ is below $70 \%$ predicted. ${ }^{24}$

The FEV , was slow to recover after propranolol challenge. In adults the $\mathrm{FEV}_{1}$ was found to be over $80 \%$ of the baseline value after one hour. ${ }^{5}$ After 90 minutes the recovery of $\mathrm{FEV}_{1}$ was complete in only five of the 12 children, suggesting fixed binding of propranolol to the $\beta$ receptor, or delayed excretion of propranolol as a result of lipophilic properties and preferential binding to albumin. ${ }^{25} 26$

Provocation with inhaled propranolol can be applied to children with asthma to assess the contribution of the $\beta$ adrenergic system to the regulation of bronchial smooth muscle tone. It has, however, several disadvantages by comparison with histamine or methacholine provocation tests. These are the long duration of the test, the prolonged action of propranolol, and the fact that only the children with substantial hyperreactivity react to propranolol.

We wish to thank Leonie Logman, Obbe Norbruis, and Robert Bloem for their skilful technical assistance; Lodewijk Martijn for the illustrations; and Barbara Elliot for reviewing the text. The study was supported by the Nederlands Astma Fonds (grant 32.019).

\section{References}

1 McNeill RS. Effect of a beta-adrenergic blocking agent, propranolol, on asthmatics. Lancet 1964;ii:1101-2.

2 Zaid G, Beall GN. Bronchial response to beta-adrenergic blockade. $N$ Engl J Med 1966;275:580-4.

3 Wunderlich J, Macha HN, Wudicke H, Huckauf H. Betaadrenoreceptor blockers and terbutaline in patients with chronic obstructive lung disease. Effects and interaction after oral administration. Chest 1980; 78:714-22.

4 Beumer HM. Inhalation of beta-adrenergic blockers by asthmatics. Lancet 1967;ii:993.

5 Gökemeyer JDM. Hyperreactivity of the airways. Thesis, 1976.

6 Meurs H, Koëter GH, de Vries K, Kauffman HF. The beta adrenergic system and allergic bronchial asthma: changes in lymphocyte beta-adrenergic receptor number and adenylate cyclase activity after an allergen induced asthmatic attack. J Allergy Clin Immunol 1982;70:272-80.

7 Knol K. A clinical and epidemiological study of the significance of bronchial hyperreactivity in children with chronic specific lung disease (CNSLD). Thesis, 1965.
8 Bhagat RG, Grunstein MM. Comparison of responsiveness to metacholine, histamine and exercise in subgroups of asthmatic children. Am Rev Respir Dis 1984;129:221-4.

9 Hargreave FE, Dolovich J, O'Byrne PM, Ramsdale EH, Daniel EE. The origin of airway hyperresponsiveness. $J$ Allergy Clin Immunol 1986;78:825-32.

10 Barnes PJ. Neural control of human airways in health and disease. Am Rev Respir Dis 1986;134:1289-314.

11 Barnes PJ. Endogenous catecholamines and asthma. $J$ Allergy Clin Immunol 1986;77:791-5.

12 Polgar G, Promadhat B. Pulmonary function testing in children. Philadelphia: WB Saunders, 1971.

13 Gerritsen J, Koëter GH, Akkerboom HJ, Knol K. Recovery of $\mathrm{FEV}_{1}$ after histamine challenge in asthmatic children. Clin Allergy 1987;17:119-26.

14 Sterk PJ, Plomp A, Crombach MJJS, van de Vate JF, Quanjer PH. The physical properties of a jet nebulizer and their relevance for the histamine provocation test. Bull Eur Physiopathol Respir 1983;19:27-36.

15 Eiser NM, Kerrebijn KF, Quanjer PH. Guidelines for standardization of bronchial challenges with (nonspecific) bronchoconstricting agents. Bull Eur Physiopathol Respir 1983;19:495-514.

16 MacDonald AG, Ingram CG, McNeill RS. The effect of propranolol on airway resistance. $\mathrm{Br} J$ Anaesth 1967;39:919-26.

17 Thomson NC, Daniel EE, Hargreave FE. Role of smooth muscle alpha 1 -receptors in nonspecific bronchial responsiveness in asthma. Am Rev Respir Dis 1982;126:521-5.

18 Barnes PJ, Ind PW, Brown MJ. Plasma histamine and catecholamines in stable asthmatic subjects. Clin Sci 1982;62:661-5.

19 Terpstra GK, Raaijmakers JAK, Wassink GA. Propranolol induced bronchoconstriction: a non-specific side-effect of beta-adrenergic blocking therapy. Eur $J$ Pharmacol 1981;73:107-8.

20 Koëter GH, Meurs H, de Monchy JGR, de Vries K. Protective effect of disodium cromoglycate on propranolol challenge. Allergy 1982;37:587-90.

21 Ind PW, Barnes PJ, Brown MJ, Dollery CT. Plasma histamine concentration during propranolol induced bronchoconstriction. Thorax 1985;40:903-9.

22 Dunn TL, Gerber MJ, Shen AS, Fernandez E, Iseman MD, Cherniack RM. The effect of topical ophthalmic instillation of timolol and betaxolol on lung function in asthmatic subjects. Am Rev Respir Dis 1986;133:264-8.

23 Juniper EF, Frith PA, Dunnett C, Cockcroft DW, Hargreave FE. Reproducibility and comparison of responses to inhaled histamine and methacholine. Thorax 1978;33:705-10.

24 Hargreave FE, Ryan G, Thomson NC, et al. Bronchial responsiveness to histamine or metacholine in asthma: measurement and clinical significance. $J$ Allergy Clin Immunol 1981;68:347-55.

25 McAinsh J, Gay MA. Theoretical Michaelis-Menten elimination model for propranolol. Eur J Drug Metab Pharmacokinet 1985;10:241-5.

26 Zaagsma J, Meems L, Boorsma M. Beta-adrenoceptor studies. 4. Influence of albumin on in vitro betaadrenoceptor blocking and antiarrhythmic properties of propranolol, pindolol, practolol and metoprolol. Arch Pharmacol 1977;298:29-36. 